\title{
Inheritance of Chilling Injury: A Maternally Inherited Trait in Cucumber
}

\author{
Sang-Min Chung, Jack E. Staub, ${ }^{1}$ and Gennaro Fazio ${ }^{2}$ \\ U.S. Department of Agriculture, Agricultural Research Service, Vegetable Crops Unit, Department of \\ Horticulture, 1575 Linden Drive, University of Wisconsin, Madison, WI 53706
}

AdDitional INDEX wORDs. Cucumis sativus, low temperature, mitochondria, paternal inheritance, and RAPD marker

\begin{abstract}
Chilling temperatures $\left(\leq 12^{\circ} \mathrm{C}\right)$ can cause substantial economic damage to cucumber (Cucumis sativus $\mathrm{L}$.) plants. Previous studies suggest chilling tolerance trait is controlled by nuclear gene(s). To investigate inheritance of chilling injury in cucumber, cucumber lines [susceptible GY14 $\left(P_{1}\right)$, tolerant 'Chipper' $\left(P_{2}\right)$, and tolerant 'Little John' $\left(P_{3}\right)$, and their exact reciprocal $F_{1}$ and $F_{2}$ cross-progeny were evaluated to determine the inheritance of chilling injury at the first true-leaf stage when challenged at $4{ }^{\circ} \mathrm{C}$ for 5.5 hours. The mean chilling ratings [1(trace) to $9($ dead)] of progeny comparisons were $F_{1}\left(P_{1} \times P_{2}\right)=6.2$ vs. $F_{1}\left(P_{2} \times P_{1}\right)=1.6 ; F_{2}\left(P_{1} \times P_{2}\right)=6.4$ vs. $F_{2}\left(P_{2} \times P_{1}\right)=2.7 ; F_{1}\left(P_{1} \times P_{3}\right)=5.4$ vs. $F_{1}\left(P_{3} \times P_{1}\right)=1.7$; and $F_{2}\left(P_{1} \times P_{3}\right)=5.8$ vs. $F_{2}\left(P_{3} \times P_{1}\right)=2.2$. These data suggest that chilling tolerance was maternally inherited as is the chloroplast genome in cucumber. Parents, reciprocal $F_{1}$, and $F_{2}$ progeny were evaluated for variation using random amplified polymorphism DNA (RAPD). Although no maternally inherited RAPD markers were detected, polymorphic and paternally inherited RAPD bands $A D 2_{1249}, \mathrm{AV8}_{916}$, and $\mathrm{AV8} 8_{969}$ amplified by AD2 and AV8 primers were cloned and sequenced. A BLAST search of these sequences suggested that their origin is likely cucumber mitochondrial DNA. These results indicate that the mitochondria genome is not associated with the chilling tolerant trait because this genome is paternally inherited in progeny derived from this reciprocal mating. Therefore, the results of maternally inherited chilling tolerant trait and paternally transmitted mitochondria genome support that the chilling tolerant trait as identified is likely associated with the chloroplast genome which is maternally transmitted in cucumber.
\end{abstract}

Chilling injury is defined as damage causing physiological (i.e., wilting and leakage of solute) (Herner, 1990; Murata, 1990) and biochemical (i.e., increase in ethylene precursor and oxidative enzymes activity, and decrease in chlorophyll with exposure to light) (Karasev et al., 1995; Wang and Adams, 1982; Wright and Simon, 1973) changes. Such changes are induced by a temperature above the freezing point, but below $12{ }^{\circ} \mathrm{C}$ (Raison and Lyons, 1986; Saltveit and Morris, 1990). Many economically important crops such as corn (Zea may L.), cotton (Gossypium hirsutum L.), cucumber (Cucumis sativus L.), squash (Cucurbita pepo L.), and tomato (Lycopersicon esculentum L.) are chillingsensitive during vegetative and reproductive growth (Jackman et al., 1988; Markhart, 1986; Saltveit and Morris, 1990). Because vegetable crops can be damaged by chilling temperatures in the vegetative and fruiting stage, the genetic improvement of chilling tolerance is an important plant breeding objective in many crop species.

Plants respond to chilling temperatures according to their genetic constitution and growing environment. Thus, the effects of chilling can most critically be studied by using appropriate germplasm (i.e., inbred lines and their cross-progeny) grown under controlled experimental conditions (Patterson and Reid, 1990). If genetic variation for chilling injury exists between inbred lines, then chilling tolerant individuals can be selected in cross-progeny resulting from chilling tolerant $X$ sensitive matings. Theoretically, tolerant progeny will contain genomic segments (genes) present in the tolerant parent.

The genetics of low temperature stress have been studied in barley (Karsay et al., 1997), rice (Sthapit and Witcombe, 1998), tomato (Foolad et al., 1998; Vallejos and Tanksley, 1983), and cucumber (Wehner and Smeets, 1992). In barley, Karsay et al.

Received for publication 17 Sept. 2002. Accepted for publication 10 Mar. 2003. ${ }^{1}$ Corresponding author; e-mail jestaub@facstaff.wisc.edu.

${ }^{2}$ Former graduate student. Current address: USDA/ARS, Curator, Plant Genetics Research Unit, Geneva, NY 14456.
(1997) found one major locus responsible for cold tolerance. In rice, Sthapit and Witcombe (1998) reported that four traits related to chilling injury [germination, the rate of germination (RG) index, plumule greening and plumule vigor] were highly heritable in progeny derived from matings between chilling tolerant and chilling susceptible germplasm. Using isozyme markers, Vallejos and Tanksley (1983) reported that three quantitative loci associated with chilling tolerance in tomato were located on chromosome 6, 7, and 12. In cucumber, Wehner and Smeets (1992) reported that chilling tolerance is heritable, and is most likely controlled by more than one gene.

Tolerance to chilling temperatures in some plant species is controlled by nuclear genes (Foolad et al., 1998; Vallejos and Tanksley, 1983). Nevertheless, a chlorophyll deficiency was found to be associated with low temperature stress in Brassica oleracea L. (Bannerot et al., 1974; Menczel et al., 1987). This deficiency occurs in progeny when cytoplasmic male sterility (CMS) is transferred from Raphanus sativus L. to B. oleracea by conventional backcrossing.

The degree of chilling tolerant plant response is affected by various environmental factors (Lyons, 1973; Smeets and Wehner, 1997). Therefore, environmental conditions that enhance chilling stress must be identified to assess the genetic variation for this trait in plant populations. Smeets and Wehner (1997) used chilling tolerant cultigens ['Little John' (experimental designation AR79-75), 'Chipper', 'Pixie', and Wisconsin SMR 18] and chilling susceptible cultigens (GY14, 'Marketmore 76', NCSUM 28, NCSU M 29, and 'Pointsett 76') to examine chilling injury in cucumber seedlings at the cotyledonary and first true-leaf stage. Extensive experimentation led them to formulate test conditions for assessing genetic variation for chilling tolerance in cucumber. They concluded that screening for genetic variation in chilling tolerance at the whole-plant level can be effective under a set of specific environmental conditions, and that genetic variation for chilling injury was greater at the first true-leaf stage than at the cotyledon stage. Their data and various other genetic studies in 
cucumber (Aoki et al., 1988; Cabrera et al., 1992) indicate that chilling tolerance genes can be identified and genetically characterized. Therefore, a study was designed to determine the inheritance of chilling injury in cucumber. One chilling susceptible line, two chilling tolerant lines, and their cross-progeny were analyzed. Random amplified polymorphic DNA (RAPD) was then used to investigate the genetic basis of chilling injury.

\section{Material and Methods}

GermPLASM. Three cucumber lines were chosen for experimentation based on their previously determined response to chilling temperatures. Line GY14 $\left(\mathrm{P}_{1}\right)$ is chilling susceptible, while 'Chipper' $\left(\mathrm{P}_{2}\right)$ and 'Little John' $\left(\mathrm{P}_{3}\right)$ are considered chilling tolerant lines (Smeets and Wehner, 1997). Experimental lines were obtained from the USDA-ARS Cucumber Breeding Project, Madison, Wis. An initial reciprocal mating was made between GY14 and 'Little John' by hand pollination in a greenhouse at the University of Wisconsin at Madison (Expt. 1). Exact reciprocal matings were then made between GY14 x 'Chipper' and GY14 x 'Little John' to produce exact reciprocal $F_{1}$ and $F_{2}$ progeny (Expt. 2).

EVALUATION OF PLANTS IN RESPONSE TO CHILLING TEMPERATURES. Parents and progeny of reciprocal GY14 x 'Little John' and 'Little John' x GY14 matings were evaluated for response to chilling temperatures in a randomized complete block design with six replications (Expt. 1). Evaluation of chilling response was made using exact reciprocal $F_{1}$ and $F_{2}$ progeny from both GY14 x 'Chipper' and GY14 x 'Little John' matings in a randomized complete block design with three replications (Expt. 2).

Seeds from all generations (i.e., $\mathrm{P}_{1}, \mathrm{P}_{2}, \mathrm{P}_{3}, \mathrm{~F}_{1}$, and $\mathrm{F}_{2}$ ) were sown in peat pots $\left(185 \mathrm{~cm}^{3}\right)$ containing sand and peatmoss $(1$ 1 volume). Seeds of parents and progeny were germinated at 22 (light) $/ 18^{\circ} \mathrm{C}$ (dark), under a 9-h photoperiod at a light level of $600 \mu \mathrm{mol} \cdot \mathrm{m}^{-2} \cdot \mathrm{s}^{-1}$ (0800 to $\left.1700 \mathrm{HR}\right)$ supplied by cool-white fluorescent and incandescent lamps. Relative humidity (RH) was held at $60 \%$, and emerged seedlings were watered twice daily with Peter s fertilizer (20N-20P-20K) (Scotts, Marysville, Ohio) to saturation.

Seedlings whose first-true leaf were apparent but not fully expanded, were subjected to a chilling treatment of $5.5 \mathrm{~h}(0800$ to $1330 \mathrm{HR}$ ) at $4{ }^{\circ} \mathrm{C}$ (immediate and constant) where the light level was $270 \mu \mathrm{mol} \cdot \mathrm{m}^{-2} \cdot \mathrm{s}^{-1}$ supplied by only cool-white fluorescent lamps. During chilling treatment, $\mathrm{RH}$ was 52\%. After chilling, plants were returned to pretreatment conditions, and leaf damage was quantified by visual rating $5 \mathrm{~d}$ after the chilling treatment. An injury rating scale was developed that ranged from 0 to 9 ; where $0=$ no damage, 1 to $2=$ trace injury, 3 to $4=$ slight injury, 5 to $6=$ moderate damage, 7 to $8=$ advanced damage, and $9=$ dead plant (Smeets and Wehner, 1997).

DATA ANALYSES FOR INHERITANCE OF CHILLING INJURY. Data analysis used the procedure PROC GLM in SAS (SAS/STAT, 1988). Generation means, variances, and standard deviations of reciprocal $F_{1}$ and $F_{2}$ progeny made in both experiments ( 1 and 2 ) were compared by $t$ test analyses $(p<0.01)$.

DNA ISOLATION AND RAPD ANALYSES. Because reciprocal differences were detected in chilling injury in both Expt.1 and Expt. 2, RAPD markers were used to further investigate the genetic basis of chilling injury at the DNA level. Seedling leaf tissue was collected from parents (GY14, 'Chipper', and 'Little John') and exact reciprocal $F_{1}$ progeny, and stored at $-80^{\circ} \mathrm{C}$ until DNA extraction. Total DNA was extracted using the modified CTAB procedure (Maniatis et al., 1982; Staub et al., 1996), and quantified
(TD-360 mini-fluorometer, Turner Designs, Sunnyvale, Calif.) for use in RAPD polymerase chain reaction (PCR) analyses.

RAPD ANALYSIS. PCR amplifications were carried out using 1040-decamer RAPD primers (A-1 to AZ-20) from Operon Technologies (Alameda, Calif.). All PCR solutions were purchased from Promega (Madison, Wis.). Each PCR had a volume of $15 \mu \mathrm{L}$ and contained $4.0 \mathrm{~mm} \mathrm{MgCl}_{2}, 0.3 \mathrm{~mm}$ dNTPs $15 \mathrm{ng}$ DNA, 0.45 M primer, polymerase buffer, and 0.2 unit Taq DNA polymerase (Staub et al., 1996). Samples were overlaid with mineral oil, and then PCR was used using the following temperature cycling profile: $1 \mathrm{~min}$ at $94{ }^{\circ} \mathrm{C} ; 50$ cycles of $15 \mathrm{~s}$ at $93{ }^{\circ} \mathrm{C}, 90 \mathrm{~s}$ at $36{ }^{\circ} \mathrm{C}$, $120 \mathrm{~s}$ at $72{ }^{\circ} \mathrm{C} ; 6$ min at $72{ }^{\circ} \mathrm{C}$.

After PCR completion, $7 \mu \mathrm{L}$ of loading dye $(0.1 \%$ bromophenol blue, $0.1 \%$ xylene cyanoll FF, $10 \%$ Ficol) was added to each reaction tube. The samples were electrophoresed in $1.6 \%$ agarose gels $(20 \times 40 \mathrm{~cm})$ containing $0.5 \mu \mathrm{g} \cdot \mathrm{mL}^{-1}$ ethidium bromide in $0.5 \times$ TBE buffer $(0.045 \mathrm{~m}$ Tris-borate and $1.0 \mathrm{~mm}$ EDTA $\mathrm{pH}$ 8.0 ), for $3.5 \mathrm{~h}$ at $\approx 170$ volts. Banding patterns were visualized using a transilluminator (Dark Reader; Clare Chemical, Denver, Colo.) that does not use UV light, then captured with a digital camera, and recorded using Gel Expert (Nucleotech Corp., San Mateo, Calif.). Polymorphic bands were named according to their RAPD primer name and base-pair length (Horejsi et al., 2000; Staub et al., 1996).

Cloning, SEQuencing, AND ANALYSEs. Several amplicons were suspected to be paternally transmitted because of their consistent presence and absence in exact reciprocal progeny comparisons during initial genetic analyses. These amplicons were excised and extracted from agarose gel using a gel extraction kit (QIAquick; QIAGEN Inc. Valencia, Calif.). The pGEM-T Easy Vector System II cloning kit (Promega, Madison, Wis.) protocol allowed for ligation of these PCR products into the pGEM-T vector, and their subsequent transformation in competent JM109 E. coli cells (Promega, Madison, Wis.). Transformed E. coli cells were rescued by incubation in $1 \mathrm{~mL} \mathrm{SOC}$ media at $37^{\circ} \mathrm{C}$ for $1 \mathrm{~h}$, plated onto ampicillin $\left(150 \mu \mathrm{g} \cdot \mathrm{mL}^{-1}\right)$ Luria-Bertani (LB) agar selection media, and then incubated for $8 \mathrm{~h}$ at $37^{\circ} \mathrm{C}$. Colonies with positive insertional events identified by blue/white visual screening were directly used for PCR amplifications using Lyse-N-Go (Pierce Company. Rockford, Ill.). Each PCR consisted of $3 \mathrm{~mm} \mathrm{MgCl}, 0.2$ mM dNTPs, 15 to $20 \mathrm{ng}$ of DNA, and $0.4 \mu \mathrm{m}$ of each M13 forward and reverse primer provided by the Biotechnology Center at the University of Wisconsin, Madison. Excess dNTPs and unincorporated primers were removed from the remaining PCR products using the ExoSAP-ITKit [United States Biochemicals Co. (USB), Cleveland, Ohio] as per the manufacturer's protocol.

To identify the origin of the paternally transmitted amplicons, the amplified fragments were sequenced using a sequencer (ABI 377; Perkin Elmer, Boston, Mass.). Sequencing reactions contained $4 \mu \mathrm{L}$ of $2.5 \times$ reaction buffer [ $5 \mathrm{x}: 400 \mathrm{~mm}$ Tris $\mathrm{pH} 9,10 \mathrm{~mm}$ $\mathrm{MgCl}_{2}$ ], $4 \mu \mathrm{L}$ of the Big Dye enzyme mix (Applied Biosystems, Foster City, Calif.), $1 \mu \mathrm{L}$ of M13 forward or reverse primer (20 pmol $\left.\cdot \mu \mathrm{L}^{-1}\right)$, and $7 \mu \mathrm{L}$ of distilled water. Sequencing reactions were performed using a thermal cycler (model 9700; Perkin Elmer) following the cycling profile: $95^{\circ} \mathrm{C}$ for $3 \mathrm{~min} ; 50$ cycles of $95^{\circ} \mathrm{C}$ for $20 \mathrm{~s}, 55^{\circ} \mathrm{C}$ for $30 \mathrm{~s}, 60^{\circ} \mathrm{C}$ for $4 \mathrm{~min}$, and then 72 ${ }^{\circ} \mathrm{C}$ for $7 \mathrm{~min}$.

All sequences were aligned and analyzed using GeneTool 1.0 software (BioTools Inc., Edmonton, Alberta, Canada, http: //biotools.com). Database searches for sequence homology assessment were performed using the U.S. Center for Biotechnology information BLAST algorithm (Altschul et al., 1990). 


\section{Results}

INVESTIGATION OF CYTOPLASMIC EFFECTS. Comparisions using a reciprocal progeny set from GY14 x 'Little John' matings (Expt. 1 ). The mean chilling injury ratings in progeny from $F_{1}$ and $F_{2}$ populations of $\mathrm{P}_{1} \times \mathrm{P}_{3}$ matings was 6.27 and 5.48, respectively (Table 1 ; Expt. 1). In contrast, the mean injury rating of progeny from reciprocal $\mathrm{F}_{1}$ and $\mathrm{F}_{2}$ from $\mathrm{P}_{3} \times \mathrm{P}_{1}$ matings was 2.06 and 1.68 , respectively. Significant $(p<0.01)$ reciprocal differences were detected between these reciprocal $F_{1}$ and $F_{2}$ cross progeny sets suggesting that cytoplasmic factors may control chilling injury in cucumber. However, because these reciprocal progeny were developed from different parental plants (i.e., different GY14 parents were used for GY14 x Little John and Little John x GY14 matings), exact reciprocal $F_{1}$ and $F_{2}$ progeny were subsequently developed to test the hypothesis that chilling injury is cytoplasmically inherited in cucumber.
RECIPROCAL COMPARISONS USING EXACT RECIPROCAL PROGENY SETS FROM GY14 X 'CHIPPER' AND GY14 X 'LITTLE JOHN' MATINGS (EXPT. 2). The mean chilling injury rating of GY14 x 'Chipper' and 'Chipper' $x \mathrm{GY} 14 \mathrm{~F}_{1}$ progeny was 6.22 and 1.56 , respectively (Table 2; Expt. 2). The mean chilling injury ratings of reciprocal GY14 x 'Chipper' and 'Chipper' x GY14 $F_{2}$ progeny were 6.43 and 2.70, respectively. Likewise, the mean chilling damage ratings of reciprocal GY14 x 'Little John' and 'Little John' x GY14 $F_{1}$ progeny were 5.44 and 1.67 , respectively, and the ratings of reciprocal GY14 x 'Little John' and 'Little John' x GY14 $F_{2}$ progeny were 5.77 and 2.20 , respectively.

IDENTIFICATION AND CHARACTERIZATION OF PATERNALLY TRANSMITTED MOLECULAR MARKERS. Genetic variation in the parental lines $\left(\mathrm{P}_{1}, \mathrm{P}_{2}\right.$, and $\left.\mathrm{P}_{3}\right)$ and exact reciprocal $\mathrm{F}_{1}$ progeny were assessed by 1,040 decamer RAPD primers. Although maternal transmission of marker-trait association was not detected,

Table 1. Mean, standard deviation, and range of chilling injury $\left(4^{\circ} \mathrm{C}\right.$ for $\left.5.5 \mathrm{~h}\right)$ in parental cucumber lines (Cucumis sativus L.) (GY14 and 'Little John') and their reciprocal $\mathrm{F}_{1}$ and $\mathrm{F}_{2}$ progeny (Expt. 1).

\begin{tabular}{|c|c|c|c|c|}
\hline Generation & $\begin{array}{l}\text { No. of plants } \\
\text { examined }\end{array}$ & Mean $^{2}$ & $\begin{array}{l}\text { Standard } \\
\text { deviation }\end{array}$ & Range \\
\hline \multicolumn{5}{|c|}{$\overline{\text { GY14 }\left(\mathrm{P}_{1}\right) \times \text { Little John }\left(\mathrm{P}_{3}\right)}$} \\
\hline GY14 $\left(\mathrm{P}_{1}\right)$ & 13 & 5.23 & 0.93 & $4-7$ \\
\hline Little John $\left(\mathrm{P}_{3}\right)$ & 14 & 1.57 & 0.51 & $1-2$ \\
\hline $\mathrm{F}_{1}\left(\mathrm{P}_{1} \times \mathrm{P}_{3}\right)$ & 15 & 6.27 & 1.03 & $4-8$ \\
\hline $\mathrm{F}_{2}\left(\mathrm{P}_{1} \times \mathrm{P}_{3}\right)$ & 56 & 5.48 & 1.31 & $2-7$ \\
\hline \multicolumn{5}{|c|}{ Little John $\left(\mathrm{P}_{3}\right)$ x GY14 $\left(\mathrm{P}_{1}\right)$} \\
\hline $\mathrm{GY} 14\left(\mathrm{P}_{1}\right)$ & 17 & 5.18 & 0.88 & $3-6$ \\
\hline Little John $\left(\mathrm{P}_{3}\right)$ & 18 & 2.22 & 0.55 & $1-3$ \\
\hline $\mathrm{F}_{1}\left(\mathrm{P}_{3} \times \mathrm{P}_{1}\right)$ & 16 & 2.06 & 0.44 & $1-3$ \\
\hline $\mathrm{F}_{2}\left(\mathrm{P}_{3} \times \mathrm{P}_{1}\right)$ & 57 & 1.68 & 0.60 & $1-3$ \\
\hline \multicolumn{5}{|c|}{ Reciprocal mean comparisons } \\
\hline $\mathrm{F}_{1}$ & \multicolumn{4}{|c|}{$\mathrm{P}_{1} \times \mathrm{P}_{3}(6.27)$ vs. $\mathrm{P}_{3} \times \mathrm{P}_{1}(2.06) * * *$} \\
\hline $\mathrm{F}_{2}$ & \multicolumn{4}{|c|}{$\mathrm{P}_{1} \times \mathrm{P}_{3}(5.48)$ vs. $\mathrm{P}_{3} \times \mathrm{P}_{1}(1.68)^{* * *}$} \\
\hline
\end{tabular}

ㄱant subjected to $4{ }^{\circ} \mathrm{C}$ for $5.5 \mathrm{~h}$, where $0=$ no damage, 1 to $2=$ trace, 3 to $4=$ slight, 5 to $6=$ moderate, 7 to $8=$ advanced, and $9=$ dead.

**Significant reciprocal differences at $p<0.01$.

Table 2. Mean, standard deviation, and range of chilling injury $\left(4{ }^{\circ} \mathrm{C}\right.$ for $\left.5.5 \mathrm{~h}\right)$ in parental lines, and exact reciprocal $\mathrm{F}_{1}$ and $\mathrm{F}_{2}$ progeny as evaluated in controlled environment replicated trials (Expt. 2).

\begin{tabular}{|c|c|c|c|c|}
\hline Generation & $\begin{array}{l}\text { No. of plants } \\
\text { examined }\end{array}$ & Mean $^{z}$ & $\begin{array}{l}\text { Standard } \\
\text { deviation }\end{array}$ & Range \\
\hline$\overline{\mathrm{GY} 14\left(\mathrm{P}_{1}\right)}$ & 9 & 6.11 & 0.78 & $5-7$ \\
\hline Chipper $\left(\mathrm{P}_{2}\right)$ & 9 & 2.00 & 0.71 & $1-3$ \\
\hline Little John $\left(\mathrm{P}_{3}\right)$ & 9 & 1.67 & 1.12 & $1-4$ \\
\hline \multicolumn{5}{|c|}{ GY14 $\left(\mathrm{P}_{1}\right)$ and Chipper $\left(\mathrm{P}_{2}\right)$} \\
\hline $\mathrm{F}_{1}\left(\mathrm{P}_{1} \times \mathrm{P}_{2}\right)$ & 9 & 6.22 & 1.39 & $3-7$ \\
\hline $\mathrm{F}_{2}\left(\mathrm{P}_{1} \times \mathrm{P}_{2}\right)$ & 30 & 6.43 & 1.70 & $3-9$ \\
\hline $\mathrm{F}_{1}\left(\mathrm{P}_{2} \times \mathrm{P}_{1}\right)$ & 9 & 1.56 & 0.73 & $1-3$ \\
\hline $\mathrm{F}_{2}\left(\mathrm{P}_{2} \times \mathrm{P}_{1}\right)$ & 30 & 2.70 & 0.99 & $1-5$ \\
\hline \multicolumn{5}{|c|}{ Reciprocal mean comparisons } \\
\hline $\mathrm{F}_{1}$ & \multicolumn{4}{|c|}{$\mathrm{P}_{1} \times \mathrm{P}_{2}(6.22)$ vs. $\mathrm{P}_{2} \times \mathrm{P}_{1}(1.56)^{* * *}$} \\
\hline $\mathrm{F}_{2}$ & \multicolumn{4}{|c|}{$\mathrm{P}_{1} \times \mathrm{P}_{2}(6.43)$ vs. $\mathrm{P}_{2} \times \mathrm{P}_{1}(2.70)^{* * *}$} \\
\hline \multicolumn{5}{|c|}{ GY14 $\left(\mathrm{P}_{1}\right)$ and Little John $\left(\mathrm{P}_{3}\right)$} \\
\hline $\mathrm{F}_{1}\left(\mathrm{P}_{1} \times \mathrm{P}_{3}\right)$ & 9 & 5.44 & 2.07 & $2-9$ \\
\hline $\mathrm{F}_{2}\left(\mathrm{P}_{1} \times \mathrm{P}_{3}\right)$ & 30 & 5.77 & 1.74 & $2-9$ \\
\hline $\mathrm{F}_{1}\left(\mathrm{P}_{3} \times \mathrm{P}_{1}\right)$ & 9 & 1.67 & 0.87 & $1-3$ \\
\hline $\mathrm{F}_{2}\left(\mathrm{P}_{3} \times \mathrm{P}_{1}\right)$ & 30 & 2.20 & 0.96 & $1-4$ \\
\hline \multicolumn{5}{|c|}{ Reciprocal mean comparisons } \\
\hline $\mathrm{F}_{1}$ & \multicolumn{4}{|c|}{$\mathrm{P}_{1} \times \mathrm{P}_{3}(5.44)$ vs. $\mathrm{P}_{3} \times \mathrm{P}_{1}(1.67)^{* * *}$} \\
\hline $\mathrm{F}_{2}$ & \multicolumn{4}{|c|}{$\mathrm{P}_{1} \times \mathrm{P}_{3}(5.77)$ vs. $\mathrm{P}_{3} \times \mathrm{P}_{1}(2.20)^{* * *}$} \\
\hline
\end{tabular}

aPlant subjected to $4{ }^{\circ} \mathrm{C}$ for $5.5 \mathrm{~h}$, where $0=$ no damage, 1 to $2=$ trace, 3 to $4=$ slight, 5 to $6=$ moderate, 7 to $8=$ advanced, and $9=\operatorname{dead}$.

**Significant reciprocal differences at $p<0.01$. 


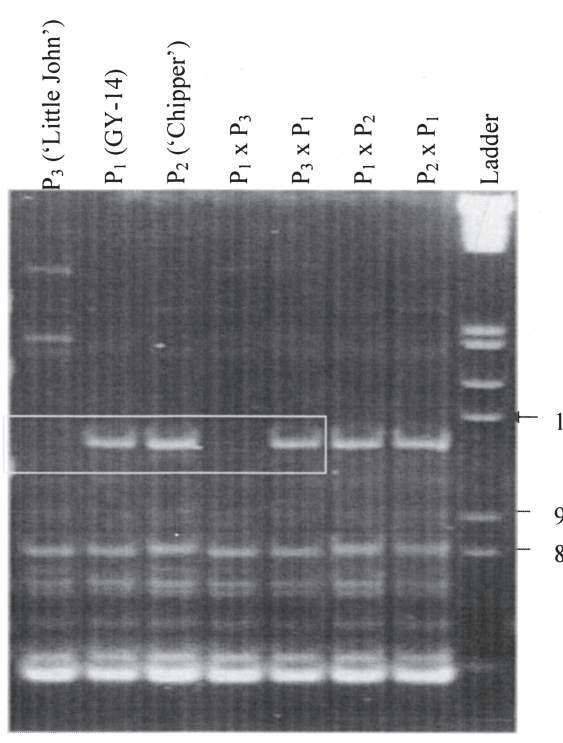

Panel A
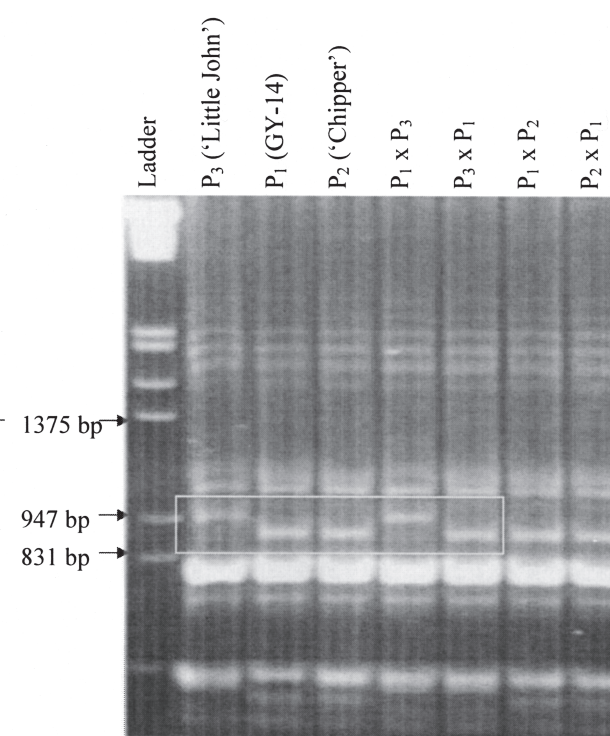

$$
\text { Panel B }
$$

Fig. 1. Amplifications of paternally transmitted RAPD markers [Operon primers AD2 (A) and AV8 (B) where lane ladder = Lambda DNA EcoRI+HindIII size ladder]. Boxes indicate location of polymorphic bands.

two primers (AD2 and AV8) were identified to be polymorphic between $\mathrm{P}_{1}$ and $\mathrm{P}_{3}\left(\mathrm{AD} 2_{1249}, \mathrm{AV} 8_{969}\right.$, and $\left.\mathrm{AV} 8_{916}\right)$, and then, by $\mathrm{F}_{1}$ cross-progeny comparisons, found to be paternally inherited (Fig. 1). BLAST searches were conducted using the paternally inherited sequences derived from the analysis of $\mathrm{AD} 2_{1249}, \mathrm{AV} 8_{969}$, and $\mathrm{AV} 8_{916}$. The sequence for $\mathrm{AD} 2_{1249}$ was matched to two $C$. sativus mitochondrial genomic sequences (GenBank accession number; AF290225 and AF290229) and AV8 sequences were likewise matched to $C$. sativus mitochondrial genomic sequences (GenBank accession number; AF290266, AF282397,AF290215, AF282392, and AF282398).

\section{Discussion}

Corriveau and Coleman (1991) investigated the inheritance of chloroplast DNA in cucumber, and concluded that because chloroplast DNA was not detected in the pollen, chloroplast DNA was maternally inherited. Likewise, foliage development in plants can be inhibited after exposure to chilling temperatures through impairment of the chlorophyll biosynthetic pathway (Feierabend, 1977; Hasselt and Strikwerda, 1976; Tewari and Tripathy, 1999). Moreover, chlorophyll biosynthesis in chilling stressed seedlings in cucumber cv. Poinsett was shown to be inhibited by $90 \%$ (Tewari and Tripathy, 1998).

Significant reciprocal differences detected between progeny derived from the $\mathrm{P}_{1} \times \mathrm{P}_{3}$ mating in Expt. 1, indicating cytoplasmic control of this trait (Table 1). The cytoplasmic control of traits in cucumber is, however, rare (Staub and Kupper, 1985). Thus, if variation for chilling susceptibility existed among GY14 plants, differences in chilling response might have been predicted in reciprocal $F_{1}$ progeny. Consequently, exact reciprocal $F_{1}$ and $F_{2}$ progeny were developed from both $\mathrm{P}_{1} \times \mathrm{P}_{2}$ and $\mathrm{P}_{1} \times \mathrm{P}_{3}$ matings (Table 2) to confirm reciprocal differences in chilling temperature response observed in reciprocal $F_{1}$ and $F_{2}$ progeny of $\mathrm{P}_{1} \times \mathrm{P}_{3}$ matings (Table 1). Because significant reciprocal differences were also detected when exact reciprocal progeny sets were challenged by exposure to chilling temperature, the cytoplasmic control of chilling tolerance in cucumber was confirmed (Table 2). Moreover, when a chilling tolerant parent (either $\mathrm{P}_{2}$ or $\mathrm{P}_{3}$ ) was used as the maternal parent in these strategic crosses, $\mathrm{F}_{1}$ and $\mathrm{F}_{2}$ progeny were uniformly chilling tolerant. In contrast, if the chilling susceptible line $\left(\mathrm{P}_{1}\right)$ was used as the maternal parent, $F_{1}$ and $F_{2}$ progeny were uniformly chilling susceptible. These results indicate that chilling tolerance trait is maternally inherited in cucumber.

Recently, segregation analysis of restriction fragment length polymorphisms (RFLP) in cucumber revealed that the mitochondrial genome is paternally inherited in cucumber (Havey, 1997). Moreover, assessment of reciprocal progeny using RAPD markers and their sequence homology from the BLAST search in this study demonstrated the paternal transmission of mitochondrial DNA in $\mathrm{P}_{1} \times \mathrm{P}_{3}$ mating progeny (Fig. 1). These results support the hypothesis that the mitochondrial genome present in the $\mathrm{P}_{1} \times \mathrm{P}_{3}$ mating is paternally transmitted. Thus, data lead to the conclusion that the genetic factors present in mitochondrial genome, as identified in $\mathrm{P}_{1} \times \mathrm{P}_{3}$ matings, are not likely to be factors controlling chilling injury in cucumber.

Although relatively uncommon, control of economically important traits such as chilling response by the chloroplast genome does occur (Menczel et al., 1987). For instance, chloroplast incompatibility between the nucleus of Brassica oleracea and cytoplasm of Raphanus sativus results in chlorosis when plants are exposed to suboptimal temperatures. Heath and Earle (1996) reported that this low temperature chlorosis phenomenon could be overcome by replacing the chloroplast genome of $B$. oleracea with that of Brassica napus L. Chilling response data of reciprocal cross-progeny reported herein strongly suggests that chilling injury in cucumber may be conditioned by chloroplast genes. This likelihood and the fact that paternal inheritance via the mitochrondrial genome exsits in cucumber suggest that cytoplasmic inheritance in this species is multifaceted and complex.

The pedigree of the cucumber lines used in this study are complex, and thus the cytoplasmic source of chilling tolerance and susceptibility is difficult to determine. Little John was developed by the initial intercrossing of PI 197087 (India), Model , Pixie, line SC601M (South Carolina), and line VB65-3 (Arkansas) (personnal communication, Dr. T. E. Morelock, University of Arkansas). Likewise, Chipper was developed by complicated intercrossing of Asgrow seed company lines (now Seminis Inc., Oxnard, Calif.), PI 197087, and PI 196289 (India). Line GY14 (released by Clemson University, Charleston, S.C.) was developed by matings between line GY-3 (released by Clemson University) and Wis. SMR18 (released by University of Wisconsin, Madison, Wis.). The parentage of line GY-3 includes PI 197087, PI 196289, PI 220860 (India), and proprietary Asgrow lines. Although the gynoecious line GY-3 was likely used as the maternal parent in the development of line GY14, the origins of GY14 cannot be unequivocally determined. Likewise, because of the proprietary nature of germplasm used in the development of Chipper, the source of its cytoplasmic constitution cannot be identified.

Differences in chloroplast DNA sequences as assessed by RAPD markers were not detected between the chilling tolerant and susceptible parental lines used in this study. Although these results suggest that the cucumber chloroplast genome is 
highly conserved, additional research is necessary to identify and characterize the genetic factor(s) associated with chilling tolerance. This will require the creation of unique genetic stocks (i.e., nearly-isogenic or inbred backcross lines). Because of their homozygous nature, uniform genetic background, and contrasting genetic constitution, such stocks will greatly facilitate physiological experiments designed to define the biochemical and molecular mechanisms that regulate chilling tolerance in cucumber.

\section{Literature Cited}

Altschul, S.F., W. Gish, W. Miller, E.W. Myers, and D.J. Lipman. 1990. Basic local alignment search tool. J. Mol. Biol. 215:403-410.

Aoki, S., M. Oda, and M. Nagaoka. 1988. Chilling and heat sensitivities in cucumber seedlings measured by chlorophyll fluorescence. Bul. Natl. Res. Inst. Veg. Orn. Plant Tea Jpn. 2:81-92.

Bannerot, H., L. Boulidard, Y. Cauderon, and J. Tempe. 1974. Transfer of cytoplasmic male sterility from Raphanus sativus to Brassica oleracea. Proc. Eucarpia Meet. Cruciferae 25:52-54.

Cabrera, R.M., M.E. Saltveit, Jr., and K. Owens. 1992. Cucumber cultivars differ in their response to chilling temperatures. J. Amer. Soc. Hort. Sci. 117:802-807.

Corriveau, J.L. and A.W. Coleman. 1991. Monitoring by epifluorescence microscopy of organelle DNA fate during pollen development in five angiosperm species. Dev. Biol. 147:271-280.

Feierabend, J. 1977. Capacity for chlorophyll synthesis in heat bleached 70 S ribosome-deficient rye leaves. Planta 135:83-88.

Foolad, M.R., F.Q. Chen, and G.Y. Lin. 1998. RFLP mapping of QTLs conferring salt tolerance during germination in an interspecific cross of tomato. Theor. Appl. Genet. 97:1133-1144.

Hasselt, P.R. and J.T. Strikwerda. 1976. Pigment degradation in discs of the thermophillic Cucumis sativus as affected by light, temperature, sugar application and inhibitors. Plant Physiol. 37:253-257.

Havey, M.J. 1997. Predominant paternal transmission of the mitochondrial genome in cucumber. J. Heredity 88:232-235.

Heath, D.W. and E.D. Earle. 1996. Synthesis of Ogura male sterile rapeseed (Brassica napus L.) with cold tolerance by protoplast fusion and effects of atrazine resistance on seed yield. Plant Cell. Rpt. 15: 939-944.

Herner, R.C. 1990. The effects of chilling temperatures during seed germination and early seedling growth, p. 51-69. In: C.Y. Wang (ed.) Chilling injury of horticultural crops. CRC Press, Boca Raton, Fla.

Horesjsi, T., J.E. Staub, and C. Thomas. 2000. Linkage of random amplified polymorphic DNA markers to downy mildew resistance in cucumber (Cucumis sativus L.). Euphytica 115:105-113.

Jackman, R.L., R.Y. Yada, A. Marangoni, K.L. Parkin, and D.W. Stanley. 1988. Chilling injury. A review of quality aspects. J. Food Sci. 11:253-277.

Karasev, G.S., N.V. Astakhova, L.A. Raikhman, and T.I. Trunova. 1995. Effect of low positive temperature on protein concentration and cell ultrastructure in cucumber and tomato plants. Fiz. Rast. Mos. 42: 855-861.

Karsay, I., K. Meszaros, Z. Bedo, P.M. Hayes, A. Pan, and F. Chen.
1997. Genetic analysis of the components of winterhardiness in barley, Hordeum vulgare L. Acta Biol. Hung. 48:67-76.

Lyons, J.M. 1973. Chilling injury in plants. Annu. Rev. Plant Physiol. 24:445-466.

Maniatis, T., E.F. Fritsch, and J. Sambrook. 1982. Molecular cloning: A laboratory manual. Cold Springs Harbor Publ., Cold Springs Harbor, N.Y.

Markhart, A.H. 1986. Chilling injury: A review of possible causes. HortScience 21:1329-1333.

Menczel,L., A. Morgan, S. Brown, and P. Maliga. 1987. Fusion-mediated combination of Ogura-type cytoplasmic male sterility with Brassica napus plastids using X-irradiated CMS protoplasts. Plant Cell. Rpt. 6:98-101.

Murata, T. 1990. Relation of chilling stress to membrane permeability, p. 201-209. In: C.Y. Wang (ed.). Chilling injury of horticultural crops. CRC Press, Boca Raton, Fla.

Patterson, B.D. and M.S. Reid. 1990. Genetic and environmental influences on the expression of chilling injury, p. 87-112. In: C.Y. Wang (ed.) Chilling injury of horticultural crops. CRC Press, Boca Raton, Fla.

Raison, J.K. and J.M. Lyons. 1986. Chilling injury: A plea for uniform terminology. Plant Cell Environ. 9:685-686.

Saltveit, Jr., M.E. and L.L. Morris. 1990. Overview on chilling injury of horticultural crops, p. 3-15. In: C. Y. Wang (ed.). Chilling injury of horticultural crops. CRC Press, Boca Raton, Fla.

SAS Institute. 1988. SAS/STAT user's guide. Release 6.03 ed. SAS Inst.. Cary, N.C.

Smeets, L. and T.C. Wehner. 1997. Environmental effects on genetic variation of chilling resistance in cucumber. Euphytica 97:217-225.

Staub, J.E. and R.S. Kupper. 1985. Results of the use of Cucumis sativus var. hardwickii germplasm following backcrossing with Cucumis sativus var. sativus. HortScience 20:436-438.

Staub, J.E., J. Bacher, and K. Poetter. 1996. Sources of potential errors in the application of random amplified polymophic DNAs in cucumber. HortScience 31:262-266.

Sthapit, B.R. and J.R. Witcombe. 1998. Inheritance of tolerance to chilling stress in rice during germination and plumule greening. Crop Sci. 38:660-665.

Tewari, A.K. and B.C. Tripathy. 1998. Temperature-stress-induced impairment of chlorophyll biosynthetic reactions in cucumber and wheat. Plant Physiol. 117:851-858.

Tewari, A.K. and B.C. Tripathy. 1999. Acclimation of chlorophyll biosynthetic reactions to temperature stress in cucumber (Cucumis sativus L.). Planta 208:431-437.

Vallejos, C.E. and S.D. Tanksley. 1983. Segregation of isozyme markers and cold tolerance in an interspecific backcross of tomato (Lycopersicon esculentum, Lycopersicon hirsutum). Theor. Appl. Genet. 66: 241-247.

Wang, C. Y. and D. O. Adams. 1982. Chilling-induced ethylene production in cucumbers Cucumis sativus L. Plant Physiol. 69:424-427.

Wehner, T.C. and L. Smeets. 1992. Inheritance of chilling resistance in cucumber. HortScience 27:611.

Wright, M. and E.W. Simon. 1973. Chilling injury in cucumber leaves. J. Expt. Bot. 24:400-411. 